\title{
EXPERIÊNCIAS LEITORAS DE UMA LEITURA LITERÁRIA SUBJETIVA'
}

\section{READING EXPERIENCES OF A SUBJECTIVE LITERARY READING}

\author{
Maria de Fátima Berenice da $\mathrm{Cruz}^{2}$
}

RESUMO: O presente texto demarca o espaço da experiência de um observatório de leitura para educação básica, composto por estudantes do curso de Letras que encontram-se em processo de formação inicial para docência. Os atores aqui envolvidos na experiência participaram do Componente curricular Literatura e Recepção entre os meses de outubro de 2019 a fevereiro de 2020. Foi utilizado como técnica de coleta as rodas de conversas (gravadas), as séries didáticas de leitura e a produção de relatos e diários de leitura. Esse material coletado foi analisado à luz do Método recepcional (ROUXEL), da produção de subjetividade (CANDAU, ECO, BARTHES) do conceito de Memória (RICOEUR, MANGUEL) para então chegarmos ao entendimento de como seria a educação literária de caráter emancipatório (COSSON, GOMES).

PALAVRAS-CHAVE: Leitura. Literatura. Leitor.

ABSTRACT: This text demarcaes the space of experience of a reading observatory for basic education, composed of students of the Course of Letters who are in the process of initial formation for teaching. The actors involved in the experiment participated in the Curriculum and Reception Curriculum Component between October 2019 and February 2020. It was used as a technique to collect the wheels of conversations (recorded), the didactic series of reading and the production of reports and reading journals. This collected material was analyzed in the light of the Reception Method (ROUXEL), the production of subjectivity (CANDAU, ECO, BARTHES) of the concept of Memory (RICOEUR, MANGUEL) and then we could come to understand what emancipatory literary education (COSSON, GOMES).

KEYWORDS: Reading. Literature. Reader.

\footnotetext{
${ }^{1}$ Artigo recebido em 10 de fevereiro e aceito em 05 de abril de 2021.

2 Professora Doutora da UNEB. Membro permanente do Programa de Pós-Graduação em Crítica Cultural, Líder do Grupo de pesquisa GEREL. E-mail: fatimaberenice@terra.com.br. ORCID: https:// orcid.org/0000-0003-0884-8535.
} 


\section{Flores que leem: experimentos de um diário literário ${ }^{3}$}

Quando participo de congressos, seminários e debates em escolas com professores de Língua Portuguesa há quase uma unicidade nos discursos de palestrantes e professores de que o ensino da literatura na escola precisa ser modificado porque não é mais atraente para o estudante. Entretanto, fico a questionar: se há essa consciência de que o modelo utilizado para o ensino do texto literário está fadado ao insucesso, por que a escola continua a manter os estudos de características estéticas e históricas das obras? Por que a escola insiste em utilizar o texto literário como pretexto à compreensão gramatical? Por que a escola insiste em ler excertos, resumos e resenhas de textos em detrimento do texto completo? Por que a escola utiliza a didática da avaliação objetiva para aferir a subjetividade do estudante?

Estas questões são provocações necessárias para que o leitor possa entender que não basta diagnosticar o problema, considerando resultados visíveis. É imperioso abrir uma séria investigação sobre as causas reais que levaram o estudante a afastar-se do prazer pelo texto literário, para que a partir dessa análise seja possível chegar a uma terapêutica para o problema. É exatamente essa investigação que venho desenvolvendo há 15 anos com resultados presentes nos diversos artigos que escrevo sobre o ensino de literatura na escola.

Contudo, aqui neste texto não me aterei a refletir sobre os problemas do ensino da literatura, mas ao contrário, apresentarei uma experiência de ensino e aprendizagem com o texto literário que se contrapõe a todas as lamúrias e sofrimentos propalados pela escola em seus discursos. Enquanto professora e leitora de literatura, sempre foi muito óbvio para mim que o ensino e aprendizagem do texto teria que ser algo prazeroso. Nunca tive dúvidas de que a aula de literatura só fluiria bem se houvesse uma completa simbiose entre texto e leitor.

Esse entendimento me levou, em primeiro lugar, a uma imersão nos estudos da recepção (Wolfgang Iser, Robert Jauss, Roland Barthes, Umberto Eco) e mais adiante (em comunhão com a educação literária) ao método recepcional (Annie Rouxel,

${ }^{3}$ Este artigo traz parte dos resultados alcançados durante a pesquisa de Estagio Pós-doutoral em Letras, realizado no PPGL/UFS, na área de Estudos Literários, entre 2019 e 2020. 
Vicent Jouve, Neide Rezende, Carlos Magno Gomes). Esses estudos me proporcionaram o seguinte questionamento: é possível desenvolver na escola um trabalho com o texto literário que priorize o lugar de fala do estudante e, ao mesmo tempo, não se desvincule dos propósitos didáticos disciplinares? Esta inquietação move os meus estudos porque faz parte dos meus cuidados desde 2006 quando resolvi iniciar um trabalho de experiência literária com leitores reais.

Muitos foram os ateliers de leitura literária que venho desenvolvendo nesses últimos 15 anos. Contudo, trago neste texto uma experiência realizada com estudantes do curso de Letras Vernáculas no componente curricular "Literatura e Recepção" que considero relevantes nessa minha trajetória de pesquisa. A experiência ocorreu em 2019 na modalidade presencial com finalização em 2020 na modalidade remota em função da Pandemia provocada pelo vírus Sars-CoV2. Essa experiência será aqui relatada e, ao mesmo tempo, mediada por intervenções teóricas, pertinentes ao campo de estudo explorado.

Mudar a forma de concepção e trabalho com o texto literário no processo de escolarização não é algo fácil nem para o estudante, nem para o professor. Por isso é que essa mudança precisa ser construída através da conquista, conjugada com elementos da ludicidade que tanto encanta crianças, jovens e adultos. Com esse pensamento iniciamos o trabalho no componente "Literatura e Recepção" (ano 2019), composto por 12 estudantes, com a seguinte dinâmica: apresentamos numa única tela de PowerPoint 15 imagens de flores denominadas, rosa, cravo, margarida, camélia, hortênsia, jasmim, azaleia, lírio orquídea, girassol, tulipa, angélica, amarílis, violeta e antúrio. Na sequência fiz uma exposição do histórico de cada flor e em seguida solicitei que eles escolhessem a flor que mais se identificava com a sua identidade e com a sua história de vida.

Assim que todos escolheram a sua flor preferida, dando à escolha uma justificativa, essas flores passaram a ser os seus nomes no "jardim da literatura", como passei a denominar o nosso espaço de estudo. Imediatamente todos foram ao celular ler um pouco sobre a sua flor escolhida e logo iniciaram os seus depoimentos sobre a suas inclinações para com a determinada flor e a relação da escolha com a sua história de vida e leitura. Creio que é 
pouco científico revelar que foi um momento muito emocionante em que percebemos a força que a arte exerce na vida do sujeito.

Todavia, devemos considerar que ao trabalharmos com a arte, seja ela de qualquer natureza, inevitavelmente os arroubos produzidos pela subjetividade irão aflorar. E nesse caso não é salutar que reprimamos os discursos dos estudantes, mesmo que estes venham recheados de emoções. A complexidade subjetiva advinda da natureza da arte gera, muitas vezes, insatisfação por parte dos docentes em virtude da crença de que a escolarização do texto literário elimina os momentos de contemplação, deleite e emoção. Contudo, esse comportamento técnico que a escola quer impor às aulas de leitura literária, não só afasta o estudante como transforma o ensino do texto literário um estorvo para discentes e docentes.

Frente a isso, a escola precisa promover aos estudantes ações leitoras que os façam encontrar na arte o caminho da sua liberdade intelectual. E essa liberdade só poderá ser alcançada quando o sujeito for capaz de utilizar a sua língua como instrumento de edificação de si, do outro e do mundo. Pois como diz Freire: "o ato de conhecer envolve um movimento dialético que vai da ação à reflexão sobre ela e desta a uma nova ação" (2002, p. 60). E ao referir-se à força da palavra na vida do sujeito, ele acrescenta: "assim como não é possível linguagem sem pensamento e linguagem-pensamento sem o mundo a que se referem, a palavra humana é mais que um mero vocábulo - é palavração" (2002, p. 59). A concepção de Paulo Freire de que a palavra é a verdadeira ação do sujeito, representa a força que a literatura pode exercer na vida de homens e mulheres que precisam conhecer os seus direitos de expressar-se e de expressar o mundo através da possibilidade da criação, da recriação e da decisão.

Então, quando afirmo que é pouco científico falar das emoções dos estudantes, na verdade eu acabo criando uma contradição para tudo aquilo que eu acredito em relação à força que o texto literário exerce sobre nós leitores. $\mathrm{O}$ texto literário se utiliza da linguagem livre e desobediente, intentando criar estruturas linguísticas que conduzam o homem a pensar a sua situação de sujeito no universo. E desta forma proporciona ao leitor uma clara compreensão de seus sentimentos e ideias. Foram esses sentimentos e ideias que tomaram o lugar na cena daquele jardim literário. 
À proporção que escolhiam a flor à qual seriam referenciados a partir daquele momento, os estudantes foram mostrando a força, a beleza, a leveza, a diversidade, a fragilidade características de cada flor que escolhiam e, dessa forma, comparavam-nas com a sua personalidade. Pude observar como a referida atividade foi capaz de fazer os participantes mergulharem sobre si mesmos, emergindo daí discursos poéticos sobre a relação de sua personalidade com a flor de sua preferência. Ali passei a ouvir a história de leitura de cada estudante (flor) desde a sua mais tenra idade. A ouvidoria ao estudante nesse processo inicial de formação leitora é de fundamental importância para que o pesquisador possa identificar a relação dos sujeitos com os seus universos de leitura, observando os entraves que porventura existam em alguns estudantes e, principalmente, o interesse temático de cada participante do grupo.

Nesse processo de ouvidoria encontramos histórias muito interessantes e inusitada como a da estudante "Rosa" que relatou sobre o seu bloqueio para com a leitura literária. Segundo ela, até os cinco anos tinha o hábito de ouvir muitas histórias para dormir contadas pelo pai. Contudo, em decorrência do seu falecimento precoce, essa prática de leitura diária desapareceu da sua vida e desde então ela evita ler narrativas. Todavia, não sabe informar conscientemente a razão do seu afastamento da leitura e, ao mesmo tempo, da sua opção pelo curso de Letras Vernáculas.

O estudante "Cravo" por sua vez, contou que desde cedo lia muito em virtude de sua mãe e sua avó serem professoras e levarem livros para casa. Considerando que ele tinha poucos recursos para outro tipo de Lazer, recorria aos livros da série vagalume que a mãe trazia da escola. Já a estudante "Margarida", filha de pais evangélicos, sempre teve muita curiosidade por narrativas diferentes das encontradas nos livros bíblicos. Desse modo, ela tomava de empréstimo livros considerados "proibidos" pelos pais e os lia na madrugada após eles dormirem; sendo muitas vezes surpreendida pelo pai no meio da noite, tendo que lançar o livro embaixo do travesseiro.

As estudantes "Jasmim" e "Camélia" disseram que descobriram a leitura por necessidade de aprovação no vestibular. Segundo elas nunca tiveram interesse em ler qualquer livro literário. Entretanto, ao entrarem no cursinho pré-vestibular iniciaram o 
contato com resumos de obras literárias e a partir daí decidiram pelo curso de Letras Vernáculas. A estudante "Violeta", de forma decidida, afirma que o texto literário que Ihe chama a atenção é aquele que apresenta questões sociais e de raça. Para ela faz-se necessário ler textos que tragam questões de sua identidade para que possa buscar a libertação das humilhações sofridas.

Semelhante a estudante "Violeta" a estudante "Orquídea" inicia sua história de leitura dizendo que sua busca pela universidade é para reparar o sofrimento de sua mãe negra, solteira e empregada doméstica. Para ela, ler e conhecer é sinônimo de sobrevivência. Os outros participantes escolheram a sua flor preferida, mas não se sentiram à vontade para falar da suas histórias de leitura. Já prevíamos esse silêncio, pois quando nosso grupo de pesquisa trabalha para organizar as atividades, deixamos sempre claro que a ouvidoria do pesquisador não deve exigir a fala do estudante. Ao contrário, o estudante precisa saber com autonomia o momento certo da sua exposição desejosa. Assim, ao construir o seu discurso partindo do pressuposto do desejo, o estudante consegue que sua criação discursiva tenha um novo valor, isto é, passa de simples utilização comunicativa da linguagem para uma ferramenta de poder e emancipação do sujeito.

Após a ouvidoria solicitamos que os participantes elencassem temáticas do seu interesse para o desenvolvimento de futuros trabalhos com o texto literário. Muitas foram as temáticas escolhidas por eles, se configurando num rico repertório de textos para serem lidos, debatidos e reescritos durante o curso. Solicitamos também que eles trouxessem para o próximo encontro um texto do gênero fábula que poderia ser coletado em livros, internet ou elaborado por eles mesmos. Entendo que permitir a inserção nas aulas de literatura de produções autorais é criar condições para que a linguagem literária do estudante assuma aspectos de representação e demonstração da linguagem, dando-lhes condições para que possam refletir sobre a própria língua como lugar da liberdade. A linguagem literária permite que as palavras assumam vida própria, com novas significações que não aquelas a elas conferidas usualmente e, desse modo a linguagem passa a ter "sabor". Um sabor que advém da composição alquímica do olhar daquele que escreve e da percepção ativa do leitor frente as palavras de uma linguagem literária que assume novos significados e representações. 
Eu costumo denominar as atividades desenvolvidas no Componente "Literatura e recepção" de momentos literários. Vale esclarecer que estou chamando as atividades de "momentos" porque após 16 semanas de encontros, muitas atividades são repetidas até mesmo por necessidade de reforço. Então, seleciono aqui os momentos de maior impacto produtivo para apresentação e consequente apreciação. Então, como devolutiva à solicitação de que trouxessem uma fábula para o nosso encontro, os estudantes-flores resolveram em sua maioria criar as suas próprias fábulas.

Lírio trouxe a fábula "Quem rir o dente cai"; Violeta trouxe "Escamas reluzentes"; Margarida "O sapinho surdo"; Camélia "O canto do galo" e Jasmim "O mosquito e o touro". Os demais: Girassol, Amarilis, Rosa e Tulipa optaram por fábulas de Esopo, La Fontain e Alberto Filho. Abrimos, portanto, uma roda de conversa cujo objetivo era fazer com que eles lessem os seus textos (autorais ou não) e os outros passassem a ser os seus leitores e comentadores. A cada leitura que os estudantes faziam dos textos dos colegas, percebíamos a força discursiva que cada fábula carregava e a força do ato criativo de sujeitos que diziam não saber escrever; mas que diante da folha em branco transformaram o real em ficção e viram na ficção a possibilidade de ler o real.

É exatamente nesse sentido que entendemos a literatura como expressão do real. Essa expressão carrega a euforia de não deixar que a realidade seja misteriosa ou mesmo absurda, mas que seja sentida em toda plenitude dos poros do leitor. Essa ação sensível do leitor só é possível porque o texto literário trapaceia a opacidade da realidade e coloca sobre ela a engenhosa liberdade. Ao falar do poder da escrita literária, Barthes (2004, p. 30) diz que ela "institui um contínuo credível, mas cuja ilusão é estampada, é o termo último de uma dialética formal que vestiria o fato real com as roupas sucessivas da verdade, depois da mentira denunciada". Na concepção de Barthes o texto literário permite a criação de novas realidades, conferindo às palavras uma verdadeira heteronímia das coisas. Essa heteronímia pode ser melhor entendida quando se entende que esta linguagem, como já dito anteriormente, é livre para conferir novos significados às palavras. É aquilo que Eco (2004, p. 37) chamou de espaços brancos, de interstícios a serem preenchidos. É por isso que ela joga com os signos ao invés de reduzi-los a um universo já determinado. 
Nessa perspectiva de representação Antônio Cândido nos diz que "A arte, e, portanto a literatura é uma transposição do real para o ilusório por meio de uma estilização formal da linguagem, que propõe um tipo arbitrário de ordem para as coisas, os seres, os sentimentos" (CANDIDO, 1972, p. 53). Ao fazer esta afirmativa Candido fala da indispensável presença de um elemento de manipulação técnica, o qual é fator determinante para a classificação de uma obra como literária ou não. Este elemento entende-se, é a linguagem classificada por Barthes como a linguagem literária, a qual estabelece uma nova ordem para as coisas representadas, mantendo uma ligação com a realidade natural.

Após esse momento de produção e leitura de fábulas, outro momento que se tornou importante no Observatório "Literatura e Recepção" foi quando discutimos o sentido da leitura literária na escola. Iniciamos com uma exposição sobre o modelo de ensino de literatura cultuado pela Educação Básica, o qual recebeu muitas críticas negativas dos estudantes que reafirmaram o seu descontentamento com a forma tecnicista como são apresentados os textos literários nas aula de Língua Portuguesa. Em seguida a turma foi dividida em 4 grupos e cada grupo recebeu um conto. Dois grupos receberam o conto "Brigadeiro de ouro" e os outros dois grupos receberam "Nascimento da separação", ambos da escritora com pseudônimo Mafra Rubra. A tarefa era leitura livre e livre apresentação interpretativa.

O primeiro grupo, após leitura e discussão do conto "Brigadeiro de ouro" criou uma dramatização do texto com um recorte especial para as personagens do pai, da mãe e da jovem. Os demais personagens foram abolidos da cena porque os estudantes entenderam que o importante seria focar no cerne da trama. O segundo grupo, leitor do mesmo conto, optou por um teatro mudo, atendendo a necessidade de criarmos outras linguagens inclusivas para o ensino da literatura. Esse grupo se preocupou com possíveis alunos surdos que estivessem presentes na aula e desse modo, deram ênfase à linguagem de sinais para produzir a encenação do texto.

O terceiro grupo responsável pela leitura do conto "Nascimento da separação" resolveu recriar o texto literário colocando em diálogo com o gênero jornalístico. Os estudantes desse grupo questionaram o impacto que determinados gêneros têm na socie- 
dade e, assim, resolveram reescrever o conto no formato jornalístico e ao apresentarem abriram um debate sobre: qual das duas linguagens impactaria mais o público? Essa autonomia que o estudante adquire ao trabalhar o texto demonstra a efetividade de alimentarmos uma proposta de emancipação intelectual do sujeito no ato da leitura. E como nos diz Lerner (2002, p. 21) "o possível é fazer o esforço de conciliar as necessidades inerentes à instituição escolar com o propósito educativo de formar leitores e escritores".

Já o quarto grupo optou por uma mesa de discussão sobre o papel da figura materna dentro do seio familiar. O referido grupo gerou uma discussão muito polêmica, visto que envolvia uma representação (secularmente inspirada na imagem da Virgem Maria) e que agora no âmbito do debate estava sendo pensada como uma identidade que antes de ser mãe, era mulher e, portanto, teria toda liberdade de escolha em ficar ou abandonar a família. A despeito das concepções religiosas sobre a figura materna, a equipe demonstrou muito amadurecimento ao defender o seu ponto de vista sobre o papel da mulher/mãe na sociedade. Notamos com o resultado dessas atividades que embora a literatura permita a criação de novos universos, as leituras acabam sendo baseadas ou inspiradas, na realidade da qual o leitor participa. Daí a afirmação de que a literatura é vinculada à realidade, mas dela foge através da estilização de sua linguagem. E como diz Barthes (2004, p. 11), "o estilo é como uma dimensão vertical e solitária do pensamento".

Isso nos leva a refletir que estando a literatura ligada à demonstração do real, esta assume funções que atuam diretamente no homem, pois que o exprime e, depois elas voltam para sua formação. Marisa Lajolo (1981, p. 38) ao falar da importância da linguagem literária, afirma "a relação que as palavras estabelecem com o contexto, com a situação de produção da leitura faz a linguagem tornar-se literária quando seu uso instaura um universo, um espaço de interação de subjetividade entre autor e leitor, escapando ao imediatismo, à predictibilidade e ao estereótipo das situações e usos da linguagem que configuram a vida cotidiana". Assim, pensar a literatura na escola é antes de tudo acreditar que esta contribuirá para a construção e consequentemente a formação de jovens e adultos numa perspectiva humanizadora e libertária. 
Outro momento de prática literária que vale a pena destacar é a exposição sobre o método recepcional, filiado aos estudos de Annie Rouxel. A exposição foi crucial para que déssemos início a uma nova etapa em nossa atividade. Os estudantes iriam, naquele momento, iniciar a atividade de "cartas dos leitores" e para isso eles precisavam estar seguros e confiantes sobre o papel do leitor diante do texto literário; posto que incentivar a escrita de cartas pelo leitor faz parte do propósito da pesquisa que realizamos há mais de uma década. A princípio essa atividade parece ser algo muito simples. Contudo, é muito complexo para muitos estudantes quebrarem com algumas conservas que lhes foram impostas ao longo do tempo pela própria escola; ou seja, de que a obra de arte é incontestável; de que o escritor é o senhor do conhecimento; de que não cabe ao leitor emitir parecer sobre a escrita do autor; enfim, uma série de mitos/medos que são produzidos no âmbito escolar sobre a relação do leitor com a obra literária.

Então, partindo desse equívoco relacional a aula expositiva sobre o método recepcional foi útil para que fosse possível reunir e apresentar elementos teóricos que enfatizassem o valor e a importância do texto literário no processo de ensino e aprendizagem de estudantes, objetivando discutir o texto literário como objeto capaz de suscitar no discente o desejo de encontrar-se com o texto e de transformá-lo em instrumento de emancipação. Nessa perspectiva Annie Rouxel afirma que:

Tanto para o professor quanto para o aluno é preciso renunciar à imposição de um sentido convencionado, imutável, a ser transmitido. A tarefa, para ambos, é mais complexa, mais difícil e mais exultante. Trata-se de partir da recepção do aluno, de convidá-lo à aventura interpretativa com seus riscos, reforçando suas competências pela aquisição de saberes e de savoir-faire (2013, p. 6).

Vista por esse anglo, a leitura do texto literário passa a ser uma ferramenta de formação do indivíduo, que através do contato com outros leitores passam a ser construtores do seu próprio conhecimento. É o que afirmam Menezes e Gomes ao dizer: "Esse processo de formação do leitor é detectado a partir dos conhecimentos prévios e da realidade sociocultural dos/as 
estudantes, suas crenças, atitudes, educação e valores" (2016, p. 166). Destarte, partindo das suas crenças, eles voltaram aos textos que antes tinham sido dramatizados ou discutidos e iniciaram a produção de cartas dos leitores a partir do diálogo com as suas histórias de vida.

Quando a atividade foi realizada pela primeira vez, alguns não se aventuraram a escrever suas cartas, mas participaram da leitura das cartas dos colegas com debates e opiniões. Não daria aqui para destacar todas as cartas, mas trarei uma amostra para que possamos entender o valor discursivo e emancipatório que a atividade proporciona. Ao escrever sobre "O brigadeiro de ouro" Camélia diz:

Caro escritor, sua personagem principal trouxe-me a lembrança de várias "Claras" que pude conhecer ao longo de minha vida, umas tiveram o mesmo final que a sua, outras não ceifaram suas vidas literalmente, mas vive uma sobrevida por serem rotuladas, não serem escutadas, vistas como sem futuro e terem tirado suas expectativas e sonhos, além de não puderem ser o que desejam. (Carta do leitor, 01/2020)

\section{Em outra carta Girassol desabafa:}

Desculpe a franqueza, mas não gostei do conto "O brigadeiro de ouro", onde fala de Clara uma menina tão dedicada com os amigos, vizinhos e familiares. Sempre agradando a todos, quase que servindo de escrava e na hora que tem um desejo, não a deixaram realizar, alegando que a menina é doente. Como doente? (Carta do leitor, 01/2020).

Ao falar do conto "Nascimento da separação" Margarida afirma:

No início Isaura me deixou intrigada, pois penso: como uma mãe pode abandonar sua própria filha? Ao ler o texto novamente pude perceber com outra visão que por trás de Isaura existia uma mulher preocupada, triste e cheia de incertezas. (Carta do leitor, 01/2020). 
Ainda sobre "Nascimento da separação" Tulipa mostra como o texto literário consegue adentrar ao corpo do leitor, fazendo-o absorver o corpo linguístico, que é o texto. E desse modo ela diz:

\footnotetext{
Desde que vi o título da obra "Nascimento da separação" fiquei imaginando o que significa a abordagem deste tema como título, mas ao iniciar a primeira linha meu coração bateu forte. Pois fui notando como essa história tem uma representatividade tão forte e original. Ela me ajudou a ter uma visão mais ampla de como uma mentira pode acabar com a vida de uma pessoa, como acabou com a de Isaura e sua família (Carta do leitor, 01/2020).
}

Esses relatos nos fazem lembrar de um belíssimo artigo intitulado "A literatura e o mundo" no qual Rildo Cosson (2006, p. 15-17) afirma que o nosso corpo é formado pela soma de vários corpos, a saber, corpo linguagem, corpo sentimento, corpo imaginário, corpo profissional e, esta mistura nos faz humanos. Apesar desta complexa formação, Cosson destaca o corpo linguagem para falar da sua matéria constitutiva - as palavras. Na sua concepção, as palavras que alimentam o corpo linguagem vêm da nossa interação com a sociedade humana e esta interação abre as possibilidades de exercício e uso da palavra. É neste ponto que ele apresenta a literatura como o lugar perfeito para o exercício do corpo linguagem e destaca que a prática da literatura, seja pela leitura, seja pela escrita, consiste em uma exploração das potencialidades da linguagem. Em outras palavras ele volta a afirmar que é no exercício da leitura e da escrita dos textos literários que se desvela a arbitrariedade das regras impostas pelos discursos padronizados da sociedade letrada e se constrói um modo próprio de se fazer dono da linguagem.

Para finalizar o artigo, Rildo Cosson volta a salientar que é na leitura e na escritura do texto literário que encontramos o senso de nós mesmos e da comunidade a que pertencemos. E reitera que a literatura nos diz o que somos e nos incentiva a desejar e a expressar o mundo por nós mesmos, pois "no exercício da literatura podemos ser outros, podemos viver como outros, podemos romper os limites do tempo e do espaço de nossa experiência e, ainda assim, sermos nós mesmos" (2006, p. 17). É exatamente 
isso que a atividade de Carta dos leitores revelou para todos nós, visto que os corpos propiciados pela força da linguagem literária, fizeram um retorno a si para compreender o seu estar no mundo.

Outra atividade que teve surpreendentes resultados, porém não mais importante que as outras já realizadas, foi "um retorno às obras de minha vida". Essa atividade consistiu em solicitar que os estudantes retomassem uma obra que já tivessem lido anteriormente e fizessem uma nova leitura com o intuito de apresentá-la ao grupo de trabalho. Eles escolheram: Capitães da areia de Jorge Amado; Vidas Secas de Graciliano Ramos; Quem é você, Alasca? de John Green; Como eu era antes de você de Jojo Moyes e Girafinha flor faz uma descoberta de Terezinha Casasanta. As apresentações foram em forma de painel de debate dos textos, tendo como parâmetro as suas práticas sociais e culturais. Partindo dos resultados dessa atividade pude perceber que o texto literário exerce fundamental importância na aprendizagem dos estudantes em fase escolar. Isto nos leva a crer que não há como negar que a escola brasileira carece de uma reestruturação na sua forma de conduzir o aluno à produção do seu próprio conhecimento.

E conforme Antônio Candido (2002), a exemplo da vida que se mostra ao homem em seus altos e baixos, "em suas luzes e sombras", a literatura educa sem se deixar prender a fins moralistas, que tentam aprisionar o texto às folhas de manuais, higienizadas pelos preceitos de virtude e de boa conduta. A produção literária tira as palavras do nada para fazer delas um todo articulado, e aí está o ponto mais importante de seu nível humanizador. A literatura "[...] não corrompe nem edifica, portanto; mas, trazendo em si o que chamamos o bem e o que chamamos o mal, humaniza em sentido profundo, porque faz viver" (CANDIDO, 2002, p. 84-85).

Partindo das vivências literárias que tivemos e, considerando que estamos num curso de formação de professores, abri uma roda de conversa para que pudéssemos programar a semana seguinte. Eles então sugeriram uma atividade intitulada, "Paródia musicalizada". Essa atividade consistia em escolher uma das obras que foram apresentadas na aula anterior e colocá-la nos grupos para que fosse transformada em paródias musicais. Desse modo, os estudantes escolheram a obra Vidas Secas de Graciliano Ramos. E estabelecendo uma articulação com o componente "Literatura e outras artes" cursado por eles no mesmo período 
do nosso trabalho, optaram por dividir a obra em quadros e para cada cena/capítulo foi construída uma paródia musical.

A transformação da forma textual prosaica para a poética exigiria em outra situação um amadurecimento maior do sujeito escrevente. Contudo, como se trata de um espaço de experiências leitoras, entendo ser pertinente incentivar o estudante a manter uma intimidade de manipulação física com o texto; pois como nos diz Gomes (2010, p. 33) “o lugar da leitura é um espaço para a formação de cidadãos conscientes da diferença como uma possibilidade cultural de relacionamento". Desse modo, foram criadas cinco paródias musicais tendo como temáticas o sertão, a família, a migração, a solidão e o amor.

Assim, voltando ao pensamento de Cândido a respeito do caráter humanizador da literatura, essas atividades que integram o leitor ao texto, corroboram a necessidade de se pensar com urgência um novo olhar da escola sobre a aquisição de uma política de leitura que mantenha docente e discente comprometidos com a construção do seu próprio conhecimento e com a transformação do seu ser no mundo através do desejo de estar com o texto. Por isso Vincent Jouve $(2012$, p. 106) nos diz que "o professor não pode se limitar ao trabalho de interpretação: ele precisa começar tornando acessíveis (fornecendo todas as informações necessárias sobre elas) as obras cuja linguagem se tornou opaca para nós". Esta concepção libertária de apreensão da leitura é que moveu todo o trabalho realizado no Observatório de leitura; visto que há entre nós pesquisadores do ensino da literatura uma preocupação em promover a autonomia política do discente e do docente frente às investidas aniquilantes do sistema dominante.

Assim, retomando uma atividade que, para mim, teria ficado incompleta em função de muitos estudantes ainda não se sentirem prontos para investirem na produção escrita, resolvi abrir uma nova roda de conversa sobre a importância da "carta do leitor" como retorno de leitura e propus que eles escolhessem um texto literário que lhes apetecessem para que pudessem escrever uma carta sobre a obra. Como sustentáculo dessa prática trouxemos o Jaime Ginzburg que nos diz: "Na escola, nos cursinhos, e em seus recursos didáticos, não há a valorização de habilidades intelectuais voltadas para a atribuição de relevância para a leitura" e mais adiante ele reitera, "Em cursos de Letras, professores 
de literatura chegam diante de seus alunos com a proposição da leitura de livros" (2012, p. 214).

Então, contrariando esse modelo os estudantes escolheram obras de: Paulo Leminski, Bráulio Bessa, Clarice Lispector, Cristiane Sobral, Álvaro Magalhães, Carina Rissi, Aleilton Fonseca, Lygia Fagundes Telles, Ana Maria Gonçalves, Luiz Eudes, Machado de Assis e Carolina Maria de Jesus. As cartas foram escritas e como resultado organizamos um livro intitulado Cartas do leitor. As cartas trazem os mais variados olhares sobre a leitura literária e também sobre outros textos trabalhados no Componente. Elas retratam ainda leituras de contos, críticas sobre a leitura na escola, o formato de educação literária oferecido às crianças e jovens e a representação literária apresentada nos livros didáticos. Contudo, o mais interessante dessa coletânea é a interação do leitor com o escritor.

Na carta à Carina Rissi, orquídea reflete:

Durante seu livro me perguntei se, por algum momento, passou por sua cabeça a ideia de tirar o leitor da realidade mesmo, inspirar a um recomeço, renovar a esperança em um novo tempo assim como aconteceu com a personagem Sofia. Adoraria que acontecesse na realidade. Ao invés do celular, abrir o livro e ir a outro época (CRUZ, 2020, p. 13).

Na carta à Aleilton Fonseca, Jasmim diz:

Como eu estou feliz em ter tido a oportunidade de me encontrar e refletir em seus personagens! Encontrar com os dramas pessoais de cada personagem me fez pensar e refletir sobre minhas próprias questões e sobre o mundo. A riqueza em sua escrita que me encanta e me faz sonhar e sofrer com os personagens (CRUZ, 2020, p. 14).

E na carta à Luiz Eudes, Rosa revela:

O seu livro me fez refletir sobre uma suposta tradição que permeia entre as gerações dos moradores da nossa cidade. Penso isso, pois ao me deparar com a história do pai de Aristeu, personagem descrito no seu livro, eu pude recordar a história que minha avó paterna conta até hoje. Minha avó também sofreu a 
brutalidade do pai, sofria e sentia dores não somente na pele, mas creio eu que também na alma, pois até hoje ela descreve as cenas com muito sofrimento nas suas narrativas (CRUZ, 2020, p. 32).

Os depoimentos dos estudantes nessa coletânea revelam que é possível transformar o espaço da sala de aula num ambiente produtivo e prazeroso, pois a leitura é uma questão pedagógica que merece toda a atenção da escola. Equivocadamente a escola encara a leitura como um instrumento útil ao aprendizado, desprezando sua função lúdica e interativa. Assim, reafirmo o meu posicionamento apresentado em $(2012$, p. 208) que ao propor uma forma de leitura homogênea, a escola privilegia a classe média em detrimento dos alunos de baixa renda. E desse modo, a ideologia escolar enfatiza a leitura parafrásica e ignora a leitura polissêmica, tirando do leitor a possibilidade de participação no texto. Aliada a essa atitude, a escola ignora o fato de que o aluno convive com outras formas de linguagem em sua comunidade, e, portanto, acaba legitimando leituras que correspondem ao gosto do docente e não a necessidade do discente.

Vale lembrar que o grupo de alunos que participou desse Observatório de leitura faz parte do corpo discente regular do curso de Letras Vernáculas da Universidade do Estado da Bahia e que, consequentemente, serão futuros professores de Língua Portuguesa. Partindo desse pressuposto e, tentando avaliar a capacidade de absorção desses estudantes em relação às práticas literárias desenvolvidas no Observatório, solicitei que formassem 5 (cinco) grupos e que cada grupo escolhesse um pequeno livro da literatura infantil para desenvolver uma aula de leitura literária para crianças do segundo ano do Ensino Fundamental I, que seria, obviamente, apresentada em formato de aula em nosso Observatório. Foi escolhido Charles na Escola de Dragões de Alex Cousseau; Tato o gato de Elvira Vigna; Como surgiram os vagalumes de Fernando Vilela e Stela Barbieri; O convidado de Raposela de Érico Assis e $O$ tapete de pele de tigre de Gerald Rose.

Pude observar nessa atividade que a tradição tecnicista do modelo de ensino sobre o texto literário está muito presente na forma de pensar e de planejar. A despeito de todos um trabalho que desenvolvemos ao longo de 45 horas de atividades lúdicas, 
promotoras da autonomia leitora dos sujeitos, no instante em que os estudantes se colocaram como condutores de atividades para crianças, ficou perceptível as marcas de uma tradição de ensino voltada para o silenciamento da criança leitora. Visivelmente percebida através de: a) explicação e interpretação antecipadas do texto literário; b) menosprezo pela reflexão do aluno; c) negligência quanto à promoção na ênfase de entonação na leitura para crianças; d) ausência de expressão corporal no ato da leitura; e) ausência da roda de conversa.

Apenas 2 (dois) grupos valorizaram o diálogo com a criança através da roda de conversa; a interação do texto literário com outras artes; o uso de fantoches para incentivo à atenção e fixação leitora e o espaço de ouvidoria à criança. Após observar esses dois universos de atividades de leitura (o observatório e a atividade planejada pelos estudantes) fica mais urgente o compromisso do pesquisador em continuar criando novos observatórios para que no futuro possamos ter uma Educação literária que desafie o fantasma do ensino literário tecnicista. Dessa maneira, escola e biblioteca devem descobrir uma adequada escolarização da leitura literária, ou seja, propiciar ao estudante uma vivência do literário, conduzir com mais frequência os jovens à práticas de leitura literária e formar leitores assíduos. Isso acabaria com a tensão existente entre o discurso pedagógico que insiste na historização do literário e o discurso de promoção e emancipação do sujeito leitor.

Em síntese, se quisermos atribuir uma função para a arte, então que ela seja educativa porque o texto literário abre sempre novas possibilidades de sentido ao leitor. Considerando esta função, podemos dizer que o sentido didático que a literatura deve ter é o de apresentar a realidade atual com seus problemas sociais, políticos, econômicos e culturais, mostrados sob a ótica da imaginação, da crítica e do lúdico, que é próprio da arte. Quando a escola passar a acreditar que é possível educar através da arte, ela conhecerá uma nova face da vida escolar, aonde o aluno vai à escola porque ele deseja desvendar a si e ao outro (CRUZ, 2012, p. 59). 


\section{Referências}

BARTHES, R. Aula. Trad. de Leyla Perrone-Moisés. São Paulo: Cultrix, 1978.

BARTHES, R. O grau zero da escrita. São Paulo: Martins Fontes, 2004.

CANDAU, J. Memória e identidade. São Paulo: Contexto, 2011.

CANDIDO, A. A literatura e a formação do homem. Ciência e Cultura. São Paulo, v. 24, p. 803-809, 1972.

CANDIDO, A. Textos de intervenção. São Paulo: Duas Cidades; Ed. 34, 2002.

CRUZ, M. F. B. Formação do leitor literário na Educação Infantil: leiturando as fábulas. Interdisciplinar, São Cristóvão, UFS, v. 31, jan.-jun., p. 43-57, 2019.

CRUZ, M. F. B. Letramento literário emancipatório para Educação Infantil: um olhar sobre o projeto Aprender, Brincar e Cantar com a turma do Sítio do Picapau Amarelo. In: Maria de Fátima Berenice da Cruz; Áurea da Silva Pereira; Maria Neuma Mascarenhas Paes. (Org.). Letramento, identidades e formação de educadores: imagens teórico-metodológicas de pesquisas sobre práticas de letramento. Campinas: Mercado de Letras, 2018, v. 1, p. 185-198.

CRUZ, M. F. B. Diversidade, Literatura e Ensino: o texto literário que a Escola baiana esqueceu. Revista Fórum Identidades, Itabaiana, UFS, v. 19, p. 69-84, 2015.

CRUZ, M. F. B. Leitura literária na escola: desafios e perspectivas de um leitor. Salvador: EDUNEB, 2012.

CRUZ, M. F. B. (Org.) Cartas do leitor. Alagoinhas: UNEB, 2020. (coletânea de cartas realizadas pelos estudantes de Letras Vernáculas - ainda não publicada)

COSSON, R. Letramento literário. São Paulo: Contexto, 2006.

ECO, Uo. Lector in fabula. São Paulo: Perspectiva, 2004.

EVANGELISTA, A. A. M. et al. A escolarização da leitura literária: o jogo do livro infantil e juvenil. Belo Horizonte: Autêntica, 2003.

FREIRE, P. Ação cultural para liberdade e outros ensaios. Rio de Janeiro: Paz e Terra, 2002.

GINZBURG, J. O ensino de literatura como fantasmagoria. Revista da ANPOLL. v.33, n.1, p. 209-222, 2012.

GOMES, C. M. Leitura e estudos culturais. In: Revista Brasileira de Literatura Comparada, n.16, 2010. 
JOBIM, J. L. Palavras da crítica. Rio de Janeiro: Imago, 1996.

JOUVE, V. A leitura. Tradução Brigitte Hervor. São Paulo: UNESP, 2002.

JOUVE, V. Por que estudar literatura? São Paulo: Parábola, 2012

LAJOLO, M. O que é literatura. São Paulo: Brasiliense, 1981.

LERNER, D. Ler e escrever na escola: o real, o possível e o necessário. Porto Alegre: Artmed, 2002.

LIMA, L. C. (Introd. e sel.) A literatura e o leitor. Textos de estética da recepção. Rio de Janeiro: Paz e Terra, 1979.

MANGUEL, A. Uma história da leitura. São Paulo: Companhia das Letras, 1997.

MENEZES, M.; GOMES, C. M. A leitura pelo horizonte dos estudos de gênero. In: GOMES, Carlos Magno; VIANNA, Beto. Ensino de língua e literatura: multimodalidade e hipertextos. Aracaju: Criação, 2016.

RICCEUR, P. A memória, a história, o esquecimento. Campinas, SP: Editora da Unicamp, 2007.

RICCEUR, P. Tempo e narrativa. Guarulhos: Wmf, 2019.

ROUXEL, A. Aspectos metodológicos do ensino de literatura. In: DALVI, M. A. et al. (Org.). Leitura de literatura na escola. São Paulo: Parábola, 2013, p. 17-33.

ROUXEL, A.; LANGLADE, G.; REZENDE, N. L. (Orgs.). Leitura subjetiva e ensino de literatura. São Paulo: Alamade, 2013.

ROUXEL, A.; Mutações epistemológicas e o ensino de literatura: o advento do sujeito leitor. Tradução de Samira Murad. Revista Criação e Crítica, n. 9, p. 1324, nov. 2012. 